\section{The Soaring of Birds}

IN the discussion about the soaring of birds which has lately been carried on in NATURE, I do not remember to have observed that any one quoted from Mr. Darwin's account of the condor. He says ("A Naturalist's Voyage Round the World," chap. ix. p. 186) :- "When the condors are wheeling in a flock round and round any spot their flight is beautiful. Except when rising from the ground, I do not recollect ever having seen one of these birds flap its wings. Near Lima, I watched several for nearly half an hour, without once taking off my eyes: they moved in large curves, sweeping in circles, descending and ascending without giving a single flap. . . The head and neck were moved frequently, and apparently with force; and the extended wings seemed to form the fulcrum on which the movements of the neck, body, and tail acted. If the bird wished to descend, the wings were for a moment collapsed; and when again expanded with an altered irclination, the momentum gained by the rapid descent seemed to urge the bird upwards with the even and steady movement of a paper kite. In the case of any bird soaring, its motion must be sufficiently rapid, so that the action of the inclined surface of its body on the atmosphere may counterbalance its gravity."

Cambridge, May I 7 JAMES CURRIE

\section{Intelligence in a $\mathrm{Dog}$}

Some time since a friend of mine, Mr. J. W. Schaub, a mechanical engineer at the Edgmore Ironworks of Wilmington, Del., informed me of an exceedingly interesting case of intelligence in a black and tan terrier belonging to him. The old mother dog and her playful family entered his bedroom while he was dressing, and one of the pups snatched his stocking as he was in the act of putting it on, running out of the room with it. The mother at once followed the young offender, took the stocking from him, and returned it to the master. $\mathrm{Mr}$. Schaub said that her conduct gave evidence of displeasure at the action of the pup, and she impressed him with the idea that she felt in some way responsible for the conduct of her young. Being greatly interested in the matter, Mr. Schaub contrived $t$ s have the offence committed on many successive mornings, the same performance being repeated each time.

$$
\text { St. Louis, U.S., April } 24
$$

FRANCIS E. NiPHER

\section{Mid-height of Sea Waves}

CAN any of your readers furnish me with the formula, or other means, for finding the difference between the mid-height of a sea-wave and the sea-level?

W. PARFITT

\section{A CURIOUS SURVIVAL}

TH $\mathrm{HE}$ thirteenth Annual Report of the Deputy Master of the Mint, just issued, contains some interesting information showing how persistently an ancient system of computing the value of bullion has survived in this country. The facts are fully set forth in an appendix to the Report by Prof. Chandler Roberts, who has recently and successfully advocated the adoption of the decimal system in the bullion transactions of the Mint. In order to make the matter clear, it may be well to state that the Troy pound, still used in this country for weighing the precious metals, is believed to have been derived from the Roman weight of $5759^{\circ} 2$ grains, the $125^{\text {th }}$ part of the large Alexandrian talent; this weight, like the Troy pound, having been divided by the Romans into I2 ounces. The earliest statute of this kingdom in which the Troy weight is named is the 2 Henry V. st. 2 , c. 4 , but the Troy weight is universally allowed to have been in general use from the time of King Edward I. The most ancient system of weights in this kingdom was the Moneyer's pound or the money pound of the AngloSaxons, which was continued in use for some centuries after the Conquest, being then known as the "Tower pound," or sometimes the Goldsmith's pound. It contained 12 ounces of 450 grains each, or 5400 grains, and this weight of silver was a pound sterling. The Tower pound was abolished in 1527 by a statute of Henry VIII., which first established Troy weight as the only legal weight for gold and silver, and from this time to the present our system of coinage has been based on the Troy weight, the Troy pound containing 5760 grains. ${ }^{1}$

The bullion transactions of the Mint have hitherto been based on an Assayer's weight termed the "carat pound," the final division of which corresponds with the number of grains in the Troy pound, and side by side with this system a curious method of expressing the 'standard' or composition of ingots or coins of gold and silver has been retained until the present year. For instance, the ordinary conception of the composition of a sovereign would be that it is an alloy or mixture of the two metals gold and copper in definite proportions, and the most simple way of expressing its contents would be to describe them as consisting of 91.66 per cent. of gold and 8.34 per cent. of copper. An assayer or bullion dealer, on the other hand, using the old system, would simply consider the composition of the coin to be gold of 'standard fineness,' that is to say, containing two carats of alloying metal in the pound; and in dealing with any particular alloy of gold and copper would in no way regard its per-centage composition, but would consider it as being so much "better" or "worse" than the one definite and legal standard, according as it contained more or less of the precious metal. The French 20 -franc piece, which contains 90 per cent. of gold, would thus be described as "worse o carats $1_{8}^{5}$ carat grains," and an Austrian ducat, which contains $98.6 \mathrm{I}$ per cent. of gold, as "better I carat $2 \frac{5}{8}$ carat grains." The cumbersome nature of this system is evident; it has the disadvantage of beirg unintelligible to those who employ the decimal system, and who are therefore in the habit of mentally referring to pure gold as Iooo. It is even found wanting in clearness by many who are conversant with the ordinary operations of coinage and bullion transactions generally. For instance, the meaning of "worse $0 \mathrm{I} \frac{5}{8}+\mathrm{I}$ " as the assay report of an ingot is at least obscure, while the equivalent statement that the standard fineness of the ingot is 900 at once suggests that IO0O parts of the metal contain 900 parts of gold.

The ancient system of reporting the results of assays possesses however many points of interest, and Prof. Roberts adds a few details respecting it, taken from a work by Snelling, ${ }^{2}$ an authority on the computation of the value of bullion, who, writing in 1766 , observes that "by the word SILVER we understand not only the metal socalled, pure and unmixed, but also when in a mass with copper ; and if but one-half, two-thirds, or any other proportional part of it be silver, yet the whole bears that name. The same is to be understood of GOLD, when by itself, or in a mass with silver and copper together, or with either of them alone."

"This is the reason that inquiries are not made, what quantity of fine gold or fine silver is contained in any mixture, which seems to be the most natural inquiry, but how much standard it holds." Thus it is that "the Assay Master, in reporting the result of an assay, does not give the absolute fineness or the quantity of fine silver or fine gold present, but only the relative quantity or fineness, that is, how much the mixture is more or less than standard. In the case of gold of 20 carats fine (or 20 parts of pure gold in 24 parts of the alloy) the assayer puts down Wo. $\underset{\mathbf{i j}+,}{\text { car. }}$ and if it is 23 carais $3 \frac{1}{2}$ grains fine,

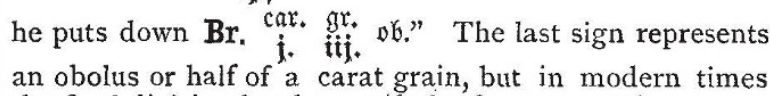
the final division has been $\mathrm{I} / 6$ oth of a carat grain.

It may be pointed out in defence of this complicated system, that, as Snelling proceeds to remark, "the quan-

I "On the Abolition of the Troy Pound," the third Report of the Commissioners appointed to inquire into the condition of the Exchequer Standards. Parliamentary paper [c. 30], 1870 .

2 "Doctrine of Gold and Silver Computations," by Thomas Snelling. (London, r 756 . 